\title{
SYMPOSIUM ON JACQUELINE PEEL \& JOLENE LIN, “TRANSNATIONAL CLIMATE LITIGATION: THE CONTRIBUTION OF THE GLOBAL SOUTH”
}

\section{THE GEOGRAPHY OF EMERGING GLOBAL SOUTH CLIMATE CHANGE LITIGATION}

\author{
Hari M. Osofsky ${ }^{*}$
}

Jacqueline Peel and Jolene Lin make an important contribution to the climate change litigation literature through their analysis of emerging climate change litigation in the Global South. Their article provides insights into patterns in that litigation and implications for how the cases may fit into transnational climate change governance. As Peel and Lin discuss, context matters greatly in establishing pathways for climate change litigation and determining regulatory impact. They acknowledge that the countries that they study as a group have significant differences among them and that these differences influence how this litigation is emerging. However, their article largely focuses on differences in legal systems and available legal mechanisms. ${ }^{1}$ This essay builds upon their article by considering how the geography of climate change interacts with this emerging litigation.

The essay begins by examining which countries from the Global South are involved, and argues that they are not a representative sample, but rather are among the largest greenhouse gas emitters and highest GDP countries in the Global South. It considers the implications of that pattern for the role of the litigation and its future pathways. The essay then turns to the substantive focus of the lawsuits and analyzes ways in which they reflect the particular geography of mitigation and adaptation in those countries. It concludes by considering how these geographic patterns might influence the future of climate litigation's impact on governance.

\section{The Geography of Countries with Climate Change Litigation}

Transnational climate change litigation interacts with the uneven pattern of greenhouse gas emissions around the world. The key pattern for purposes of this analysis is that the extent of emissions does not divide along North/South lines. Rather, a listing of the largest emitters contains countries from both the Global North and the Global South. ${ }^{2}$ However, as high-emitting countries from the Global South have emphasized in climate change negotiations, historical and per capita emissions differ significantly from total emissions; this needs to be taken into account when setting emissions reductions goals. ${ }^{3}$

\footnotetext{
* Dean, Penn State Law and School of International Affairs; Distinguished Professor of Law, Professor of International Affairs, Professor of Geography, The Pennsylvania State University.

${ }^{1}$ Jacqueline Peel \& Jolene Lin, Transnational Climate Litigation: The Contribution of the Global South, 113 AJIL 679 (2019).

${ }^{2}$ For a ranking of carbon emissions by country, see Global Carbon Atlas (Nov. 24, 2019).

${ }^{3}$ See id. For a comparison of per capita and total emissions, see Union of Concerned Scientists, Each Country's Share of CO2 Emissions (Oct. 10, 2019). These differences are captured to some extent by the differential obligations in the Paris Agreement. See Paris Agreement arts. 2 (2), 4(1) \& 4(4), Dec. 12, 2015, UNTS I-54113.
}

(C) Hari M. Osofsky 2020. This is an Open Access article, distributed under the terms of the Creative Commons Attribution licence (http://creativecommons.org/licenses/by/4.0/), which permits unrestricted re-use, distribution, and reproduction in any medium, 
Examining Peel and Lin's list of climate change cases taking place in the Global South, most of the countries in which litigation has been brought are among the most significant total emitters of carbon dioxide in the Global South and major global emitters. The countries with litigation highlighted in the article (sorted by emissions rank in world) include India (3), Indonesia (12), Brazil (13), South Africa (14), Pakistan (31), the Philippines (37), Nigeria (39), Colombia (45), Ecuador (69), and Uganda (126). ${ }^{4}$ All but two of them are in the top fifty emitters globally, and four of them are in the top fifteen.

The first countries in the Global South with emerging climate change litigation, then, are not a random sampling of developing countries or those facing the most severe adaptation challenges. Rather, as with litigation in the Global North, these cases are largely taking place in the courts of major emitter countries that also have among the highest GDPs in the world. ${ }^{5}$

Especially because this litigation is largely mitigation focused, an emphasis on major emitters makes some sense. Like with litigation in the Global North, an intervention in the approach of countries with high greenhouse gas emissions could make the most difference globally in reducing emissions.

However, this pattern also raises important questions about whether the cases are representative of the litigation that might develop over time in the Global South and about gaps in the resources needed to develop litigation in poorer countries that are highly impacted by climate change. Cases in those countries might focus more on adaptation and loss and damages in order to help bring resources to address those impacts. ${ }^{6}$ Additional research could explore why the litigation emerged first in these countries, the barriers to litigation in poorer, lower-emitter Global South countries, and strategies for addressing concerns of people in those countries.

One key complementary strategy for addressing impacts in the Global South, as highlighted in Peel and Lin's article, may also involve lawsuits brought by Global South petitioners in Global North countries rather than in their home countries. ${ }^{7}$ These suits may be able to impact the behavior of major emitter governments and corporations headquartered in those countries. They also have the potential to assist in the transferring of resources to those impacted by climate change through addressing adaptation and loss and damages in countries in the Global South where litigation has not yet been brought.

\section{The Geography of Mitigation}

Although the countries in the Global South with the most climate change litigation have both total emissions and GDP parallels with the countries in the Global North with the most litigation, the substantive focus of the cases varies somewhat between the two groups. This variation reflects differences in mitigation and adaptation challenges among these countries.

Peel and Lin highlight some of these differences in their analysis of pathways for litigation in the Global South, examining in particular six aspects of these cases: (1) whether they are core (central focus is climate change) or periphery (climate change is a more peripheral issue in the case); ${ }^{8}(2)$ their use of environmental impact assessments; (3) their greater focus on rights-based litigation; (4) their greater emphasis on enforcing existing law; (5)

\footnotetext{
${ }^{4}$ See Global Carbon Atlas, supra note 2.

${ }^{5}$ Central Intelligence Agency, Country Comparison: GDP, The World FaCtBook.

${ }^{6}$ For a discussion on the emergence of adaptation litigation in the Global North, see Jacqueline Peel \& Hari M. Osofsky, Sue to Adapt?, 99 Minn. L. Rev. 2133 (2015).

7 See Peel \& Lin, supra note 1, at 683-84, 702-03, Appendix Table 2.

8 See id. at 689 (citing Jacqueline Peel \& Hari M. Osofsky, Climate Change Litigation: Regulatory Pathways to Cleaner Energy? 8-9 (2015) for categorization of cases).
} 
their use of the public trust doctrine; and (6) the collaboration between plaintiffs and NGOs. ${ }^{9}$ This section builds upon Peel and Lin's analysis by examining what aspects of mitigation the cases address.

A focal point for climate change litigation in the United States and Australia, the two countries in the Global North that have seen the most cases, has been coal-fired power plants. This is because the transition from coal to other sources of energy is a key mitigation strategy in those countries. Both have significant coal resources, and many of the cases have focused on environmental impact assessments of coal-fired power plants and other coal projects. ${ }^{10}$

Some of the Global South mitigation cases highlighted by Peel and Lin focus on coal-fired power plants as well. For example, one of the Indonesian cases focuses on permits for coal mining. ${ }^{11} \mathrm{~A}$ Pakistani case claims public trust and rights violations based on the exploitation of fossil fuels, particularly coal. ${ }^{12}$ All three of the South African cases involve environmental impact assessment of coal-fired power plants. ${ }^{13} \mathrm{~A}$ case filed by a Peruvian farmer in Germany also involves coal-fired power plants. ${ }^{14}$

However, a number of the cases also address greenhouse gas emissions challenges that have been less of an issue in the Global North cases. For example, six of the seven Indonesian cases involved clearing of land, including illegal logging and forest-clearing and setting fire to land to clear it for palm oil cultivation. ${ }^{15}$ Brazilian cases similarly focused on the burning of sugar cane in the harvesting process, ${ }^{16}$ clearing land for grazing, ${ }^{17}$ draining and clearing a mangrove to create a landfill, ${ }^{18}$ and reforesting to offset airline emissions. ${ }^{19}$ The Colombian cases also dealt with deforestation and infrastructure development threats to high-altitude ecosystems that capture carbon. ${ }^{20}$ Indian cases addressed concerns about the conversion of farmland to industrial land, ${ }^{21}$ rickshaws as a low-carbon form of transportation, ${ }^{22}$ and the phasing out of refrigerants that are potent greenhouse gases. ${ }^{23}$ One of the cases in the Philippines addresses laws around road sharing between cars and other forms of transportation. ${ }^{24} \mathrm{~A}$ Nigerian case focuses on gas flaring, which has been a particular issue with the oil industry there. ${ }^{25}$

${ }^{9}$ See id. at $703-10$.

10 Jacqueline Peel \& Hari M. Osofsky, Climate Change Litigation: Regulatory Pathways to Cleaner Energy? (2015); Columbia Law School - Sabin Center for Climate Change Law and Arnold \& Porter Kaye Scholer LLP, U.S. Climate Change Litigation, Curmate Change Litigation Database.

11 Peel \& Lin, supra note 1, Appendix (Komari v. Mayor of Samarinda (2013)).

${ }^{12}$ Id. (Ali v. Federation of Pakistan (2016)).

${ }^{13}$ Id. (Earthlife (2017); Khanyisa Project (2017); KiPower Project (2017)).

${ }^{14}$ Id. (Lliuya v. RWE (2015)).

${ }^{15}$ Id. (MoE v. Selatnasik and Simpang (2010); MoE v. PT Merbau Pelalawan Lestari (2014); MoE v. PT Kalista Alam (2013); MoEF v. PT Bumi Mekar Hijau (2016); MoEF v. PT Jatim Jaya Perkasa (2016); MoEF v. PT Waringin Agro Jaya (2017)).

${ }^{16}$ Id. (Public Prosecutor's Office v. Oliveira (2008); Supreme Federal Court Case (2015)).

${ }^{17} \underline{I d}$. (Maia Filho v. Fed. Envtl. Agency (2015)).

${ }^{18}$ Id. (Public Prosecutor's Office v. H Carlos Scheider S/A Comercio e Industria (2007)).

${ }^{19} \underline{I d}$. (Sao Paulo Public Prosecutor's Office v. United Airlines \& Others (2014)).

${ }^{20} \underline{I d}$. (Protection of High-Altitude Ecosystem (2016); Future Generations v. Ministry of Env't (2018)).

${ }^{21}$ Id. (Karnataka Indus. Areas Dev. Board v. Sri C. Kenchappa (2006)).

22 Id. (Manushi Rickshaw Case (2010)).

${ }^{23}$ Id. (Indian Council for Enviro-legal Action (ICELA) v. Ministry of Env't, Forest and Climate Change and Others (HFC-23 case) (2015)).

${ }^{24}$ Id. (Victoria Segovia et al v. Climate Change Commission et al. (2017)).

${ }^{25}$ Id. (Gbemre v. Shell \& Others (2005)). 
These patterns reinforce that litigation strategy will vary based on the physical geography of each country and how that translates into greenhouse gas emissions. Coal-fired power plants emissions are an issue in both the Global North and Global South, but deforestation as a driver of climate change is a particular concern in the Global South and has been a major focus at the UN Framework Convention on Climate Change with the REDD+ initiative, which works to "reduce emissions from deforestation and forest degradation in developing countries." 26 Peel and Lin note that issues will vary across countries, with China more focused on air pollution and other countries more focused on deforestation. ${ }^{27}$ Geographic variation at a subnational level likely will also influence pathways for litigation, with major cities focal points for air pollution concerns and rural areas for deforestation. $^{28}$

\section{The Geography of Adaptation}

A core environmental justice problem of climate change is that many of the countries most impacted have made a minimal contribution to the problem and have limited resources to adapt. ${ }^{29}$ Increasingly, the international climate change regime has recognized that some of the impacts will be so severe that adaptation will not be possible, raising questions of loss and damage. ${ }^{30}$

Although some cases have focused on adaptation in the Global North, particularly Australia, the vast majority of cases have been mitigation-oriented. This likely reflects that Australia has faced earlier impacts from climate change than many other developed countries. ${ }^{31}$

Peel and Lin note that the Global South docket was more mitigation-oriented than originally hypothesized. ${ }^{32}$ Some of the cases deal with adaptation issues, but the first wave of Global South cases parallel the Global North ones in being largely mitigation-focused. One reason for this may be the geographic pattern noted above. Because the cases are largely taking place in developing country major emitters, the mitigation orientation makes sense. As with litigation in the developed country major emitters, petitioners are bringing actions in developing country emitters to try to reduce the greenhouse gas emissions in those countries (tailored to their particular geography as noted above).

An important strategic question is why litigation has only minimally emerged in poorer countries facing major impacts of climate change and whether it will be an effective tool in supporting adaptation in those countries. The adaptation cases in Australia arguably have been effective not only because (as Peel and Lin note) they are lower profile and less politically charged, ${ }^{33}$ but also because there are pathways to adaptation and resources to support them. Although Pakistan, where the Leghari case focused on adaptation took place, is in the Global South, its GDP

${ }^{26}$ UNFCCC REDD+ Web Platform (last visited Nov. 24, 2019).

27 See Peel \& Lin, supra note 1, at 716-17.

${ }^{28}$ For a discussion of how subnational regions and variations interact with nation-state-based treaty systems, see Hari M. Osofsky, Retbinking the Geography of Local Climate Action: Multi-Level Network Participation in Metropolitan Regions, 2015 UtAH L. Rev. 173; Hari M. Osofsky, Technology Transfer and Climate Change, in Sustainable Technology Transfer: A Guide to Global Development (Hans Henrik Lidgard et al., eds. 2011).

${ }^{29}$ Intergovernmental Panel on Climate Change, AR5 Climate Change 2014: Impacts, Adaptation, and Vulnerability (Mar. 2014).

${ }^{30}$ UN Framework Convention on Climate Change, Approaches to Address Loss and Damage Associated with Climate Change Impacts in Developing Countries.

31 See Peel \& Osofsky, supra note 6.

32 See Peel \& Lin, supra note 1 , at 715 \& n. 39.

33 See id. at 716-17. 
ranks twenty-sixth globally ${ }^{34}$ and it has a National Climate Change Policy and Framework that formed the basis for the litigation. The focus of that case was primarily on adaptation, but the scope of the decision also included mitigation concerns. ${ }^{35}$ Many of the countries in the Global South facing adaptation and loss and damages challenges are much poorer and lack the governmental and judicial infrastructure of Pakistan.

These constraints, as well as the need to seek funds from developed country major emitters and corporations, reinforce the importance of emerging cases in Global North countries by Global South petitioners referred to by Peel and Lin. The three cases filed in Europe all focused on climate change mitigation. However, the two cases in New Zealand addressed issues of climate change migration — relocation caused by climate change impacts—and may provide a model for other Global South petitioners. ${ }^{36}$ In both instances, petitioners were from Small Island Developing States in the Pacific Ocean that are extremely vulnerable to sea-level rise and severe storms. ${ }^{37}$

\section{Defining Success: Possibilities for Direct and Indirect Impacts}

Climate change litigation is a form of strategic litigation; it focuses not only on serving individual clients, but also on impacting mitigation or adaptation strategies. Peel and Lin illuminate three main ways that this emerging litigation interacts with transnational climate change governance. First, they argue that the greater prevalence of human rights approaches helps to shift the focus to fairness and mainstream human rights as part of climate change governance. Second, these cases often raise climate change as a peripheral issue situated among other sustainable development concerns, which helps situate climate change in a broader environmental and sustainable development context. Third, these emerging Global South cases create an opportunity for transnational legal dialogue amplified by South-South advocacy networks. ${ }^{38}$

This essay concludes by building upon Peel and Lin's analysis through consideration of the potential direct and indirect regulatory impacts of the emerging geography of litigation in the Global South. Peel and I developed a model for mapping these pathways to impact in our prior work. The direct impact flows from the lawsuits themselves and how their outcomes are implemented. But these lawsuits also have the potential to influence corporate, individual, NGO, and government behavior by increasing the costs of greenhouse gas emissions and by changing social norms and values. For some lawsuits, the indirect impacts can be at least as significant as the direct ones. ${ }^{39}$ Specifically, we have found in our analysis of global climate change litigation, in which we looked largely at Global North cases but also emerging cases in the Global South, that litigation's impact is greatest when the litigation is part of a broader advocacy campaign. We also have noted that a combination of high-profile and incremental cases can together be impactful. ${ }^{40}$

All three of the pathways that Peel and Lin describe involve both direct and indirect impacts. Human rights cases, because they connect the problem of climate change to particular vulnerable people, are ones in which the indirect impacts of litigation can be particularly strong. For example, the Inuit peoples' 2005 petition to the Inter-American Commission on Human Rights had limited formal success but helped bring attention to their

${ }^{34}$ Central Intelligence Agency, supra note 5.

35 Leghari v. Pakistan, W.P. No. 25501/2015, Lahore High Court, Order of Sep. 4, 2015, para. 1 (Pakistan).

36 See Peel \& Lin, supra note 1, at Appendix, Table 2.

${ }^{37}$ Id.; see also UN Dev. Programme, Small Island Nations at the Frontline of Climate Action (Sept. 18, 2017).

38 PEEL \& OsOFsKY, supra note 8.

39 Id.

${ }^{40}$ Jacqueline Peel \& Hari M. Osofsky, Litigation as a Climate Regulatory Tool, in International Judicial Practice On the Environment: Questions of Legitimacy (Christina Voight ed., 2019). 
concerns. ${ }^{41}$ The human rights cases that Peel and Lin analyze have the potential to shift the dialogue about climate change through their indirect profile-raising role, particularly if they are situated within an advocacy campaign about climate change and human rights that considers impacts in particular places and globally.

Similarly, framing these cases as part of a broader sustainable development dialogue and developing SouthSouth networks will enhance not only the development and direct outcomes of these cases, but also their indirect regulatory impact. The possibilities for emerging advocacy networks and philanthropic efforts to expand these cases in the Global South may help to situate them in broader advocacy campaigns. ${ }^{42}$ Particularly given the emissions profile and GDP of the first countries to see climate change litigation, networks and funding may play a particularly crucial role in developing capacity in a broader set of countries in the Global South.

Beyond the three pathways Peel and Lin analyze, there are some additional aspects of these initial cases relevant to assessing current direct and indirect impacts and strategies for the future. First, in at least a subset of the Global South, litigation is beginning to tackle key mitigation concerns tied to the geography of particular countries. This strategy seems like a promising approach for tailoring litigation to some of the different mitigation strategies needed in the Global South.

Second, the cases thus far also include a mix of high-profile and incremental cases. Both the Legharicase and the Philippines Human Rights Commission have received extensive media attention. However, many of the cases have been relatively low-profile and also appear to be emerging in clusters, such as the South African environmental impact assessment cases and the Indonesian cases on logging, forest clearing, and other land clearing. ${ }^{43}$

Third, the cases analyzed by Peel and Lin are all pro-regulatory. ${ }^{44}$ However, the cases in the Global North have been mixed, generally reflecting whether they are responding to a pro-regulatory or anti-regulatory administration, and some cases with positive outcomes have faced backlash. ${ }^{45} \mathrm{~A}$ key question moving forward is how, if at all, antiregulatory litigation and advocacy might emerge or interact with pro-regulatory litigation in the Global South.

In the final analysis, the geography of these initial cases suggests both opportunities to address important mitigation and adaptation concerns and the constraints that many countries in the Global South face. Peel and Lin make an important contribution through providing a systematic analysis of the cases, which hopefully will continue to develop in ways that both help to constrain emissions and to address challenges of the most impacted countries.

${ }^{41}$ For an in-depth discussion of this petition and emerging human rights cases in both the Global North and Global South, see Jacqueline Peel \& Hari M. Osofsky, Rights Turn in Climate Change Litigation?, Transnat'L EnvtL. L. 1-31 (2017).

42 See id. at 74-75.

43 See Peel \& Lin, supra note 1, at Appendix, Table 1 \& Table 2.

44 See id.

45 PeEL \& OsOFsKY, supra note 8. 